\title{
PAST AND PRESENT IN SAMUEL JOHNSON'S DICTIONARY OF THE ENGLISH LANGUAGE
}

\author{
Allen Reddick: Englisches Seminar, Universität Zürich (reddick@es.uzh.ch)
}

\begin{abstract}
Johnson's method of incorporating illustrative quotations from previous authors into his Dictionary creates a 'space of pastness,' in which some decontextualized authors can be used by Johnson to argue or represent views in the present. The illustrations quoted in the Dictionary are de-historicized; indeed the Dictionary itself is not concerned with a history of language or diachronic development. Yet one must be cautious in assessing and using evidence from the quotations. In the case of John Milton, Johnson adjusts and re-places Milton's ideological symbolic value, quoting him in rhetorically, usually self-reflexive ways, and reads him, in part, through the eyes and works of Alexander Pope. Finally, it has been shown that in the Preface to the Dictionary, Johnson thematizes the elusiveness of the present and its tragic overtones of regret, failure, and death. The Preface is preoccupied with time and time's passing.
\end{abstract}

\section{Introduction}

After the recent commemorations of the $300^{\text {th }}$ anniversary of the birth of Samuel Johnson in 1709, it seems particularly appropriate to examine Johnson's own act of looking back as performed within the great Dictionary. In particular, I would like to examine Johnson's use of published sources from his literary past (as the first lexicographer of the English language to incorporate quotations from written sources). I will look in some detail at his incorporation of quotations from the works of John Milton. In certain cases, Johnson not only positions or re-positions authors in specific ways for cultural or ideological significance, but also creates within the Dictionary, or entries within it, a 'space of past' which both marshals and incorporates voices from the past into a 'timeless' - or 'time-full' — present. In the process, he engages in a profound meditation upon time and its passage, a meditation seen most explicitly in the famous Preface to the work. The Dictionary is intimately involved with inheritance-of language, most obviously-sometimes a 
problematic inheritance. What is Johnson's relation to these writers of the past, to say nothing of the language they speak? And to what extent do they construct a de-historicized 'space of past' in the Dictionary? I would like to explore the tension between timeless and time-specific in the Dictionary. In so doing, I intend to illuminate qualities central to Johnson's book.

\section{Quotations and historicization in the Dictionary}

In his correspondence after the completion of his nearly ten years of work on the project, Johnson reflects upon the fact that lexicography of a living language is a science doomed to failure; and the larger the dictionary, the greater the failure. 'Dictionaries are like watches, the worst is better than none, and the best cannot be expected to go quite true' (Redford 1992-4: iv. 379), Johnson insisted stoically. In slightly more optimistic vein, when touting his revised dictionary of 1773 in the advertisement preceding the work: 'Perfection is unattainable, but nearer and nearer approaches may be made.' From the beginning of his work in 1746 through his periodic revisions until his death and the annotated revisions that were left unpublished, Johnson spent nearly forty years of trying to catch up with time - the moment which was always 'passing over me,' as he memorably phrased it in his Preface (Kolb and DeMaria 2005: 375 and 110, Reddick 1996: 1-11). In fact, Johnson revised no other of his works even half as thoroughly or as frequently as he did his Dictionary. This reflects a radical unease for Johnson, and an aspect of his work that recalls the anxious force behind Tristram Shandy. Sterne's fretting protagonist, writing an account of his own 'Life and Opinions,' is never able to catch up to the present moment in his life, despite his best efforts and repeated attestations of his intention to do so.

Johnson told James Boswell testily, after he goaded him about the inclusion of certain words from other dictionaries, 'Yes Sir ..., I have the words, but my business was not to make words, but to explain them' (Hill 1897: 50). On another occasion with Boswell (who productively tormented him), he 'showed Dr. Johnson verses in a magazine, on his Dictionary, composed of uncommon words taken from it ... He read a few of them, and said, I am not answerable for all the words in my Dictionary' (Hill-Powell: 1934-50, v: 273) - and he repeats this sentiment in the Preface to the Dictionary: '[I] do not form, but register the language' (Kolb and DeMaria 2005: 102). He protests, if not too much, at least enough to suggest to us that this inheritance of the English language was both liberating and burdensome. Johnson is the inheritor not only of the language, but also the literary and philological mantle, the matrix of discourse. And it is the managing of this 'authority' that seems to be one key to understanding Johnson's ambivalent relation to past writing in his Dictionary. 
Johnson announced in his Preface that he would select the overwhelming number of his 'authorities' (i.e. illustrations) from works written in a roughly 100-year period, between the time of Sir Phillip Sidney (1554-1586) and the Restoration. These works he calls 'the wells of English undefiled' (Kolb and DeMaria 2005: 95). (He did stray from this chronological boundary often, however: for example, passages from Dryden and Pope are among the most frequently quoted.) He insisted he would not quote living authors and indeed quoted very few. The decision to fill his work with citations from authorities of previous generations, indeed previous centuries, setting the terminus ante quem for selection of illustrations considerably more than a generation earlier than the period of compilation, clearly affects the type of dictionary Johnson produces. It was seen by most as a monument to the state of English letters; yet it is past written language that is cited. This characteristic of 'preteriteness' or 'pastness' is, on the one hand, characteristic of any dictionary, always attempting to capture the moment in the present which, however, remains elusive. In Johnson's case, it is overtly contradictory to base present usage on examples from the distant past. Such a work as the Dictionary collects selectively the past discursive record, becoming 'monumental' in the sense of being metonymic with memory; yet it claims to be not a historical dictionary but one reflecting the state of the English language (Reddick 1996: passim).

If Johnson 'does not form, but register[s] the language,' then this liberates him from certain responsibilities, while imposing others more neutral. It has not been sufficiently taken into consideration that the quoting of dead rather than living writers liberates the lexicographer, not from faction or intrigue or personal sympathies (as Johnson implies), but from the boundaries of the political moment, both current and former. While in this work, one apparently engages with the past rather than with the present (that is, with writers and word usage recorded from the past), Johnson may, in some cases, effectively rearrange literary and cultural history, as well as politics, under his entries to suit present needs. In fact, a strange, rhetorically-uncertain space is frequently created under entries, in which disembodied authors appear and may make pronouncements, decontextualized from the original context, yet partially recontextualized within Johnson's entries. The first purpose for which Johnson quotes a passage is exemplification of the given sense of a word heading. Beyond this, the voice and the extent of the declamation of the quoted author and passage, as well as the citation itself, are equivocal, more or less 'eloquent' depending on Johnson's arrangement of the entry and the general rhetoric allowed or encouraged under the heading or sub-heading. The quotations are concerned primarily with a fairly restricted lexical function. They are disconnected in an important sense, especially from their original contexts (Reddick 1998). Johnson can use this disembodiment to his advantage and can generate useful symbolic value from some sources. For example, Johnson added to the fourth edition a disproportionate number of quotations 
from a small cluster of theological-political writers, mainly from the $17^{\text {th }}$ century, who represented the defense of the church, in particular, from past challenges. Johnson appears to resurrect voices from the past to represent political and theological positions in the present; where they do not actually argue, it would appear that they function as reminders of past struggles and causes, reminders placed before the readers (Reddick 1996: 141-169, Reddick 1997: 983-993, 1000-1005). Johnson's attempt in this case was apparently unsuccessful and probably abandoned in the process; nevertheless, it supplies another very important aspect of the way in which Johnson attempted to utilize the inevitable 'pastness' of his work for present gain.

We could say that the Dictionary creates, not a history, but a 'space' of the past - and of 'pastness' - it brings long-dead (and usually forgotten) authors to a forum, of sorts - they are in a way resurrected in eighteenth-century garband allowed to 'function,' whatever their voice, in the agora of the assembled text. This is an aspect of what should be considered as the Dictionary's characteristic 'dehistoricizing' tendency: in this case, the earlier and frequently forgotten writers are resurrected to speak as contemporaries, of Johnson and of each other. The dehistoricization can be further illuminated by noting that, in general, Johnson makes no attempt to distinguish the earliest use of a word, despite arranging the quotations in chronological order under each definition, and only occasionally provides explicit reference to diachronic development of word meaning (he gives no dates, for example); and while he often assembles multiple quotations under individual senses, he makes no attempt to be exhaustive or representative. Instead, Johnson's attention is focused more upon specific synchronic occurrences of words in particular (though possibly typical) contexts (Reddick 1998: 72-73). (This places its purposes directly contrary to the historical concerns of the Oxford English Dictionary, for example.) One can contrast this approach with Charles Richardson's New Dictionary (1836-37), which explicitly challenged Johnson by quoting numerous authorities over a wide historical expanse to give the impression of logically developing linguistic practice; it supplied a much wider corpus of usage than Johnson, especially earlier usage, and was influential in the development of English historical semantics, especially the $O E D$ (Dolezal 2000, Murray 1993). Johnson's relation to past word usage and writers is much more contingent upon something more like chance encounter than comprehensive survey, whether synchronic or diachronic (Reddick 1998: 73). While he writes in the Preface of wishing to provide a history of 'thoughts and diction' used by writers quoted in his Dictionary, he qualifies this desire in the Plan of the Dictionary (1747) by adding that such observations are 'to be desired rather than expected' (Kolb and DeMaria 2005: 98 and 57). Some of his quotations, he concludes in the Preface, 'serve no other purpose, than that of proving the bare existence of words' (Kolb and DeMaria 2005: 94-95). Diachronic relationships or developments are rarely established. 
The Dictionary represents a special kind of history, one without apparent change or development, primarily reflected in the illustrations. Greg Clingham (2002: 9) has written:

Paradoxically...[for Johnson] while language may be changing all the time, literature (as symbolized by and manifested in the quotations in the Dictionary) is a place in which 'words' and 'things' come into approximate relationship with each other, and make for a kind of permanence and accessibility, within historical change.

This 'permanence and accessibility' of the literary texts, as I understand it, occupies a timeless present, though within historical time-in the sense of 'being surrounded but unaffected by' historical time.

\section{The nature of evidence provided by quotations}

But one must be extremely cautious in deciphering and using evidence represented by the illustrative quotations within the Dictionary. The Dictionary constitutes a rich repository of text containing an array of evidence, evidence relevant to investigations of the structure of historical, linguistic, cultural, and political phenomena. It also contains material relating to Samuel Johnson's intentions and procedures, and his attitudes to culture, politics, letters, and language, and to the writings of the ancestors he inherits. The nature of this evidence is complex, however, because of the particular type of text the Dictionary manifests. This complexity requires a particular sensitivity to the life of text, context, and intertextuality. What constitutes evidence regarding the quotations incorporated into the Dictionary, and evidence of or for what? How should the evidence be treated? For some time, in my published work, I have advised caution in this area, while exploring opportunities. Here, I will attempt to clarify what caution seems most appropriate and offer some possibilities to pursue, in particular concerning Johnson's integration of quoted authorities.

Few scholars today would make the mistake of assuming that authors quoted in the Dictionary are to be taken in their unmediated voice, or that they mouth Johnsonian views, thus committing a classic rhetorical fallacy of voice and agency. We cannot blithely insist that 'Johnson says....' Or even 'The Dictionary says ....' Or 'The discussion in the Dictionary says ....' Or 'In the Dictionary Pope insists....' Or 'the position adopted by the Dictionary is...' (Some aspects of this approach have been associated with DeMaria 1986). Few would look upon the body of the Dictionary expecting the kind of coherence or text-type (narrative, rhetorical, argumentative, educational, etc.) that one would with other kinds of texts. Yet the temptations are always there to fall into easy patterns of taking the text - specifically the authorities - at face value, which leads to a variety of fallacies. 
In examining the evidence provided by the incorporated quotations, it is necessary to take into consideration a variety of factors, of which the following are just a few. Importantly, one must consider context, both prior (i.e. within the original source) and current. One must note the extent and kind of attribution provided, which reveal the ways in which the reader is directed in a particular way to consider the source authority being quoted. The reference to a particular author or work may have specific implicit connotations, as well. The placement of the quotation in relation to the other elements of the entry, and to some extent the other entries on the page, may be relevant to an assessment of its significance, in particular the relation of quotation to definition (in the construction of the entry the definitions were, for the most part, produced by the quotations that Johnson located, marked, copied out, and gathered; Johnson did not, in most cases, begin with the definition and then seek out illustrations). One must also consider the process of how the passage was found and processed, and what was its material source, to determine the extent of Johnson's responsibility and/or intention for the quotation's presence and form in the completed entry (Reddick 1998).

In a fine recent essay, Freya Johnston (2007: 314) illustrates both the mistakes one is tempted into and the opportunities the material presents for insights into Johnson's thinking and instincts. She writes that the quotations under the entry for the word CHILD demonstrate that 'the mention of children leads [in the Dictionary] to thoughts of death' because the sources are quoted from contexts related to the death of children. Yet the quotations have been completely de-contextualized each from its own source, then re-contextualized, and make no reference whatsoever to children and deathin fact, they read, for the most part, rather promisingly in their new context concerning relations between parents, children, and fruitfulness. Regardless of previous context, how do the quotations function in the new context? Yet while Freya Johnston's comment has no bearing on the Dictionary itself, she succeeds in uncovering a pattern in the selection of passages, important possibilities for Johnson's reading, train of thought, and preoccupations, particularly displayed in his searches for illustrations. Indeed, the original contexts all do concern the death of children.

\section{Quotations from Paradise Lost}

It seems clear that some of Johnson's quoting and intertextualizing of material has relevance to his general attitudes and intentions, even if they may be unconscious or accidental. I wish to examine Johnson's treatment of Milton's poetry in the Dictionary and the ways in which he quotes, misquotes, alters, bends or breaks his material. Such usage illuminates not only Johnson's intentions for the Dictionary and Milton's place within it, but also Johnson's attitudes 
towards Milton more generally, his poetry and place, in literary as well as political history.

In the revised Dictionary and the Life of Milton, and the political pamphlets of the 1770s, Johnson aggressively repositions Milton within literary, sacred, and political history. In the Dictionary, he omits Milton's prose, the source of his politics, and in the Life, denigrates Milton's prose writings as self-interested or worse. Yet he floods the new edition of his Dictionary (1773) with new quotations from Paradise Lost (example: under GREAT, adj., no fewer than nineteen new quotations from Paradise Lost), and praises the poem as the greatest in English in his Life of Milton. This is part of an attempt to rearrange Milton's political capital and salvage his sacred worth. It is an effort of 're-placement' from historical into the timeless. As for the political pamphlets, he engages in a battle (with the likes of John Adams and others) for the meaning and use of Milton for political and cultural purposes. (Reddick 1997, Reddick 2010: 17-18).

Johnson's elevation of Paradise Lost and his adding of many new quotations from the poem are significant for their ideological and rhetorical aspects. Not only does he try to elevate the poem as the greatest in the language, outside of or beyond criticism, as it were, as the greatest English epic, but he also quotes Milton in such a way that he displays an attempt both to diminish him and to recruit him as an authority in his work. The persistence of such instances requires an explanation.

Johnson's individual instances of quoting of Milton in the Dictionary are usually, as far as one can see, innocuous or un-ideological, although there are quite a few cases which might appear to be self-reflexive, especially in consideration of Milton's biography and his symbolic capital - in other words, contexts dealing with the subversion of authority, war between heaven and hell, betrayal, etc., all potential themes that could recoil upon the author Milton, especially in the hands of the politically unfriendly Johnson. Some of these quotations may or may not be intentionally ironic. In a few cases, Johnson uses Milton in the Dictionary for mock-heroic effect, the effect mocking Milton himself. Some of these are highlighted (for the scholar at least and any interested contemporary) because they are added in the later edition, the fourth of 1773. Each is placed under potentially sensitive political words. To illustrate the definition, 'Opponent to lawful authority,' under REBELLIOUS. adj., Johnson adds the following passage from the description of Satan in Book III of Paradise Lost:

Bent he seems

On desperate revenge, which shall redound

Upon his own rebellious head. Milton.

Upon Milton's own 'rebellious head' Johnson exacts a type of revenge by forcing him down, bending him to positions or suggestions that he would in 
fact have opposed (as Cromwell's Latin Secretary and the apologist for the execution of Charles I). Characteristically, Johnson reduces Milton in stature (historically and politically speaking) while invoking his poetic presence. This constitutes a version of what Bruce Redford, in discussing Johnson's treatment of Milton in the pamphlet The Patriot, identifies Johnson to be undertaking, 'To align himself with Milton, yet repudiate him at the same time' (Redford 1990: 88). Johnson makes use of Milton's authority, and Milton (it would appear) must bend under the example of Satan (and his own) to demonstrate appropriate obeisance.

Consider the 1773, fourth edition revisions Johnson makes to his first-edition text for the entry PARDON n.s. Under the definition, 'Forgiveness of a crime; indulgence,' Johnson adds three quotations, each from Paradise Lost. Under such a sensitive entry in relation to Milton's biography, they appear to me significant in reading Johnson's attitude towards Milton: the first two, explicit and intentional self-references; the third, indicative of Johnson's attitude towards and reading of Milton. Furthermore, he drops the semantic extension, 'indulgence,' in order to put the focus on 'forgiveness' and 'crime.' The first passage, from Paradise Lost XI, 1. 167, Eve's 'But infinite in pardon is my judge,' is altered into the present tense from the poem's 'was.' The second quotation is taken from Adam's directions to Eve in Paradise Lost, X, $l l$. 1086-1090:

What better can we do than prostrate fall

Before him reverent, and there confess

Humbly our faults, and pardon beg, with tears

Wat'ring the ground?

Johnson's ironic quoting (under such a delicate entry PARDON) of Eve/ Adam/Milton's texts co-opts Milton's voice in such a way that it serves as a self-reference, and self-censorship, of Milton's own transgression, forced humility, and repentance, before his own merciful judge, Charles II, God's earthly regent. The original passage in the poem contains the spatial reference 'What better can we do than to the place/Repairing where he judged us, prostrate fall' (X, 1086-87), which is deleted in the quotation thus translating the site of the action to Milton's own situation. The passage as quoted seems an echo of the conclusion of Dryden's Absalom and Achitophel in which the monarch Charles II, God the Father, and we the reader, judge - and nod affirmatively-in perfect agreement.

The third quotation he adds would sound more like Pope's Dunciad than Milton's Paradise Lost, were it in heroic couplets:

There might you see

Indulgencies, dispenses, pardons, bulls,

The sport of Winds. 
The passage is in fact abridged from Paradise Lost, III, 11. 489-93, in which Milton describes 'the Limbo of Vanity,' a comical description of the emptiness of religious abuses and their practitioners:

Then might ye see

Cowls, hoods, and habits, with their wearers, tost

And fluttered into rags; then reliques, beads, Indulgences, dispenses, pardons, bulls,

The sport of winds:

In the mock-epic catalogue of detritus as 'sport of winds,' Milton seems to imitate Pope, rather than the other way around; the presentation of the mock-epic Milton diminishes Milton to the familiar and coarse. Johnson's quoting of half-lines disguises the blank-verse-epic lines, blurring boundaries between possible poetic modes. But Milton not only appears to be 'imitating' Pope (or a lesser mock-epic poet like Garth); as Johnson had written in his Life of Milton, '[Milton's] desire of imitating Ariosto's levity has disgraced his work [Paradise Lost] with the Paradise of Fools; a fiction... too ludicrous for its place' (Lonsdale 2006, iv: 292). Critics including Dryden, Addison, and Voltaire had objected to the episode of the limbo of vanity on the moon in Ariosto's Orlando furioso. In quoting this passage (as he does under three different entries: he quotes the passage slightly differently under DISPENSE n.s., and quotes the lines immediately following this passage under LIMBO n.s., def. 1, in the first and fourth editions.), Johnson reduces Milton in stature, reminding subtly that in his sarcasm and arrogance, Milton could also make himself ridiculous. In the progress of the entry, Milton not only repents and seeks pardon (in the first quotations), he is tamed into the mock-heroic, the heir of Dryden and Pope.

\section{John Milton, Alexander Pope, and misquotation}

Johnson often quotes, in the Dictionary and elsewhere, the following passage:

I may assert eternal providence,

And vindicate the ways of God to man. Milton.

This passage illustrates definition 4 of the verb, To VINDICATE, for example, in his Dictionary. The lines were obviously important to him, as he inserts them (in 1773) to illustrate GREAT (with 'men' for 'man'), he quotes it earlier in his Rambler 94 on Milton's prosody, and again in his Life of Milton in 1779. While the passage sounds familiar - and who does not recognize the most famous line in Paradise Lost? - the line is not Milton's. Instead, it is Pope's, from the Essay on Man, yoked by violence to Milton's invocation, above 
Milton's own name. Milton's poem reads, seemingly unforgettably, 'I may assert eternal providence,/And justify the ways of God to men' (11. 25-26). How could it have come to this: Johnson substituting a line from a poem he famously did not care for (the Essay on Man), whose theology he distrusted, for Milton's line, the very line, in Johnson's words in his Life of Milton, which delineated the 'purpose ... the most useful and the most arduous' in poetry, 'to shew the reasonableness of religion, and the necessity of obedience to the Divine Law' (Lonsdale 2006, iv: 76-77, i: 283)?

It might be insisted that the difference between 'vindicating' and 'justifying' is not great - indeed, Johnson defines the verbs similarly and in part reciprocally in the Dictionary. However, Milton's editor Thomas Newton, for one (in an edition used by Johnson), found no equivalence between the terms and criticized as petty Pope's variation: 'It is not easy to conceive any good reason for Mr. Pope's preferring the word vindicate, but Milton makes use of the word justify, as it is the Scripture word, That thou mightest be justified in thy sayings, Rom. III. 4. And the ways of God to Men are justified in the many argumentative discourses throughout the poem, and particularly in the conferences between God the Father and the Son' (Newton 1749, i.:10). Milton himself outrageously puns on the senses of 'justify,' alluding to Protestant justification by faith. Reading it as 'vindicate' alters the theology of the line: Johnson's mistake - if we assume that it is one - is hardly neutral. He incorporates Pope's cleansing of the line of its Protestant insistence. But if Johnson were not the great critic of Milton, it would seem a mere curiosity.

In the realms of religion and moral philosophy, Johnson would probably in many ways have sided more with Milton than with Pope. The opening to Pope's poem (and the entire poem itself) omits all references to revealed religion, to Christ, and to the hereafter. Pope invites comparison with Milton's breathtaking declaration of theme and intention-his claims to defend and amplify God's entire prophetic narrative scheme. Yet Pope's opening lines meander like the maze he describes (originally written 'a maze without a plan,' changed to 'but not without a plan'), and are decidedly this-worldly:

Let us (since Life can little more supply

Than just to look about us and to die) Expatiate free o'er all this scene of Man;

A mighty maze! But not without a plan;

A Wild, where weeds and flow'rs promiscuous shoot,

Or Garden, tempting with forbidden fruit....

Laugh where we must, be candid where we can;

But vindicate the ways of God to Man. (11. 3-16)

Pope himself fudges the issue in his own manuscript notes to the poem, reading his own final line as if it were Milton's: 'The last line sums up the moral and 
main Drift of the whole, [the?] Justification of the Ways of Provi[dence]' (Mack 1950: 12).

Johnson does know the difference: he quotes Milton's line nearly correctly ('To the height of this great argument/I may assert eternal providence,/And justify the ways of God to man'), with 'man' for 'men,' to illustrate the noun ARGUMENT in the Dictionary. And he quotes Pope's lines correctly, with the correct attribution, to provide an example of typeface in the Dictionary entry BURGEOIS, '2. A type of a particular sort, probably so called from him who first used it, as,' followed by Pope's couplet in Burgeois type. This example is noteworthy, as it suggests Johnson chose the quotation (unusually) from memory (it does not contain the word exemplified), as one of the most recognizable in the language, to provide an example of Burgeois type.

It would be overstating the likelihood to claim that Johnson is intentionally refashioning Milton, Paradise Lost, and its theology in the image of Pope and Essay on Man. Yet there is considerable evidence of Johnson's literal ambivalence towards Milton, and his attempts to reduce and alter Milton's voice. In the cases I have cited, Johnson seems to be reading Milton (unconsciously) through the experience of Pope's poem. If nothing else, it attests to the power of texts to penetrate consciousness and become ineradicably part of one's reading and thinking. He has read Milton through Pope's Deistic, ultimately unsympathetic eyes. It is worth mentioning that in the case of the illustration for VINDICATE, we can be fairly sure that Johnson quoted from memory (rather than mis-transcribed), for the actual word illustrated is not otherwise found in the original text, only in his own misremembering.

Does Johnson really see Milton through a filter of Pope? It is worth considering, especially in light of the strange addition to the revised edition of the Dictionary under To LOSE v.a.: Johnson adds a new definition 2, as follows: 'To forfeit as a penalty. In this sense is Paradise lost.' Illustrating this new definition is not a quotation from Milton, but from Pope's 'Temple of Fame': 'Fame- few, alas! The casual blessing boast,/So hard to gain, so easy to be lost! Pope.' Milton is 're-placed' in these places both in terms of cultural and political history, and literally re-placed by Pope.

Johnson redeems Milton from his dark historical role, disembodies him, instating him instead as the timeless sacred poet. There is a double effect being performed: Milton must recount his past sins, but can be acknowledged as knowing more about crucial themes of disobedience and anarchy than anyone.

But how far can or should we go in interpreting evidence from Milton or from any of the quoted authorities? Robert Folkenflik (2007: 11) has recently written:

We can safely say what the Dictionary thinks; it is more difficult to make claims about what Johnson thinks on the basis of Dictionary illustrations or even definitions. 
Whether or not we can agree on what the 'Dictionary thinks,' we should follow Folkenflik's skepticism in drawing unwarranted conclusions about Johnson's intentions from the text. Nevertheless, we may glimpse patterns of Johnson's thought, intentions, and execution within the intertextualities of The Dictionary of the English Language.

\section{Past and Present in the Preface to Johnson's Dictionary}

In the Preface to the Dictionary, Johnson explicitly discusses the past and thematizes the elusiveness of the present and its tragic overtones of regret, failure, and death. Perhaps the most poignant example is the following:

Those who have been persuaded to think well of my design, require that it should fix our language, and put a stop to those alterations which time and chance have hitherto been suffered to make in it without opposition. With this consequence I will confess that I flattered myself for a while; but now begin to fear that I have indulged expectation which neither reason nor experience can justify. When we see men grow old and die at a certain time one after another, from century to century, we laugh at the elixir that promises to prolong life to a thousand years; and with equal justice may the lexicographer be derided, who being able to produce no example of a nation that has preserved their words and phrases from mutability, shall imagine that his dictionary can embalm his language, and secure it from corruption and decay, that it is in his power to change sublunary nature, or clear the world at once from folly, vanity, and affectation (Kolb and DeMaria 2005: 104-105).

Johnson's text is preoccupied with time and time's passing. In contrast to the relatively de-historicized body of the Dictionary, the Preface establishes the historical author as well as the book whose creation occurred within actual history. Ruth Mack (2001: 71) refers to Johnson's self awakening 'in a collapsed identification with the form of the text produced... in Johnson's account, the mind is responsible for the text, not because it creates it, but because it exists outside of it and proves its limits in being analogous to it.' Johnson as a person living within diachronic time identifies with the Dictionary he has produced and historicizes the process (he recounts its challenges), if not the product, of the work. 'A dictionary,' observes Mack, 'cannot simply represent the present state of language as universal, Johnson laments, "since while it is hastening to publication, some words are budding, and some falling away" [Kolb and DeMaria 2005: 110]. This realization produces a...sense in which Johnson can do only what his "human powers" allow him: what he describes here is not the limit of a capacious mind or an infirm body but that of a person existing historically, in diachronic time' (72). 
It is perhaps remarkable in a document whose principle purpose is the establishing of its authority, thus requiring a history of its composition, that (with the exception of the initial paragraphs) it is not until paragraph 72 of the Preface, three-quarters of the way through, that Johnson seriously engages with the simple past tense, as he begins the narrative of 'When first I engaged in this work, I resolved ....,' leading to, 'But these were the dreams of the poet, doomed at last to wake a lexicographer' (Kolb and DeMaria 2005: 100). Until this paragraph, he virtually avoids the simple past, using the present perfect in nearly every case, as he instead projects the Dictionary into present and future discursive space. Yet the account of personal difficulties threatens insistently to break into his discourse, building with intensity as the personal voice competes with the public. In paragraph 92, the third from the end, he writes as follows:

In hope of giving longevity to that which its own nature forbids to be immortal, I have devoted this book, the labour of years, to the honour of my country, that we may no longer yield the palm of philology to the nations of the continent. The chief glory of every people arises from its authours: whether I shall add any thing by my own writings to the reputation of English literature, must be left to time: much of my life has been lost under the pressures of disease; much has been trifled away; and much has always been spent in provision for the day that was passing over me; but I shall not think my employment useless or ignoble, if by my assistance foreign nations, and distant ages, gain access to the propagators of knowledge, and understand the teachers of truth; if my labours afford light to the repositories of science, and add celebrity to Bacon, to Hooker, to Milton, and to Boyle (Kolb and DeMaria 2005: 109-110).

Johnson writes: 'much has always been spent in provision for the day that was passing over me.' Grammatically speaking, 'has ... been spent' is a past perfective formation with the adverb or time-frequency adjunct always. In this context, 'always' must be read as iterative, i.e., as a series of events; every day it happened again (i.e., not continuous duration, in other words, but at regular intervals); therefore, the past progressive 'was passing over' must also be iterative. However, in the context, the rhetorical impact and transferal of reference effects, or at least implies, something that has happened always and continuously. It 'was passing,' it always has been (and always will be) spent in provision. This is an unusual speech formation, contributing immeasurably to its strange power and the force of the entire paragraph. Note the alteration of the parallelism of the phrases in the sentence, suddenly intensifying the effect. The time-frequency adjunct 'always' implies the all-time-consuming quality of one's own physical and psychological necessities; and it further implies that, at all times, it was the day passing - indeed, passing over me - that always swallowed time, thought, and provision, and it was 'always passing,' never to be simply 
'present.' This is, of course, the crucial paradox of time. In the Preface, anguish and uncertainty are projected into an uncertain future. Furthermore, the passing over of the day depicts a Johnson removed from the time-space of that day, as if it is happening beyond himself, as if he is not living it, but it is simply passing over him, as he remains stationary.

In the concluding paragraph, Johnson recalls the labors of humankind throughout the long ages, and constructs a metonymically layered edificethe book, the concluding paragraph itself, and his own effort and life imposed one upon the other-balanced upon a fulcrum, janus-faced past, (present) and future: note the shifts of tense in the concluding paragraph, from predominantly future, to predominantly past, and ultimately finally into the present. Johnson insisted in one of his sermons that 'We are in full possession of the present moment' (Hagstrum and Gray 1978: 113). Yet writing never seems to capture that present. The possession of the present in this final paragraph is muted, the scene of sober dismissal:

In this work, when it shall be found that much is omitted, let it not be forgotten that much likewise is performed; and though no book was ever spared out of tenderness to the authour, and the world is little solicitous to know whence proceeded the faults of that which it condemns; yet it may gratify curiosity to inform it, that the English Dictionary was written with little assistance of the learned, and without any patronage of the great; not in the soft obscurities of retirement, or under the shelter of academick bowers, but amidst inconvenience and distraction, in sickness and in sorrow: and it may repress the triumph of malignant criticism to observe, that if our language is not here fully displayed, I have only failed in an attempt which no human powers have hitherto completed. If the lexicons of ancient tongues, now immutably fixed, and comprised in a few volumes, be yet, after the toil of successive ages, inadequate and delusive; if the aggregated knowledge, and co-operating diligence of the Italian academicians, did not secure them from the censure of Beni; if the embodied criticks of France, when fifty years had been spent upon their work, were obliged to change its oeconomy, and give their second edition another form, I may surely be contented without the praise of perfection, which, if I could obtain, in this gloom of solitude, what would it avail me? I have protracted my work till most of those whom I wished to please, have sunk into the grave, and success and miscarriage are empty sounds: I therefore dismiss it with frigid tranquillity, having little to fear or hope from censure or from praise [Kolb and DeMaria 2005: 111-113].

'[L]ittle to fear or hope' - the future is stalled and veiled in a liminal stasis, in the apparently uninvested act of dismissal, of sending away. Johnson ironically transforms Chaucer's trope at the end of Troilus and Criseyde, in which he 
proudly proclaims, 'Go, litel bok, go, litel myn tragedye' (11. 1786), to take its place in the pantheon of works by the great poets. Johnson pointedly steps outside of English literary history, both recalling the tradition and denying his work its place, despite his Dictionary being full of disembodied examples taken from it. In Johnson's work, full of the words of the English literary past, he rejects the inherited Chaucerian tradition, to send on its way his own ungainly offspring with his own ironic version of 'go, little book.'

\section{References}

\section{A. Dictionaries}

Johnson, Samuel. 1755. A Dictionary of the English Language, 2 vols. London: J. and P. Knapton, et al.

Johnson, Samuel. 1773. A Dictionary of the English Language, 2 vols. (Fourth edition). London: W. Strahan, et al.

\section{B. Other literature}

Clingham, G. 2002. Johnson, Writing, and Memory. Cambridge: Cambridge University Press.

DeMaria, R. 1986. Johnson's Dictionary and the Language of Learning. Chapel Hill: University of North Carolina Press.

Dolezal, F. 2000. 'Charles Richardson's New Dictionary and Literary Lexicography, being a Rodomontade upon Illustrative Examples.' Lexicographica, 16: 104-51.

Folkenflik, R. 2007. 'The Politics of Johnson's Dictionary Revisited.' The Age of Johnson: A Scholarly Annual, 18: 1-17.

Hagstrum, J. and J. Gray (eds) 1978. Samuel Johnson, Sermons. New Haven, CT: Yale University Press.

Hill, G.B. (ed.) 1897. 'Anecdotes by the Rev. Dr. Thomas Campbell.' Johnsonian Miscellanies. Oxford: Oxford University Press: ii, 39-57.

Hill, G.B. (ed.), rev. L. F. Powell. 1934-1950. Boswell's Life of Johnson, Together with Boswell's Journal of a Tour to the Hebrides. 6 vols. Oxford: Clarendon Press.

Johnston, F. 2007. 'Accumulation in Johnson's Dictionary.' Essays in Criticism, 57: 301-324.

Kolb, G. and R. DeMaria, jr. (eds) 2005. Johnson on the English Language. New Haven: Yale University Press.

Lonsdale, R. (ed.) 2006. Samuel Johnson, The Lives of the Most Eminent English Poets; with Critical Observations on their Works, 4. Vols. Oxford: Clarendon Press.

Mack, M. (ed.) 1950. Alexander Pope, An Essay on Man. London: Methuen and Co.

Mack, R. 2001. 'The Historicity of Johnson's Lexicographer.' Representations, 76: 61-87.

Murray, J. 1993. 'The Evolution of English Lexicography.' International Journal of Lexicography, 6: 100-122.

Newton, T. (ed.) 1749. John Milton, Paradise Lost: A Poem in Twelve Books. A New Edition with Notes of Various Authors, 2 vols. London: J. and R. Tonson and S. Draper. 
Reddick, A. 1996. The Making of Johnson's Dictionary, 1746-1773. (Rev. second edition). Cambridge: Cambridge University Press.

Reddick, A. 1997. 'Johnson beyond Jacobitism: Signs of Polemic in the Dictionary and the Life of Milton.' ELH: English Literary History, 64: 983-1005.

Reddick, A. 1998. 'Johnson's Dictionary of the English Language and its Texts: Quotation, Context, Anti-Thematics.' Yearbook of English Studies, 28: 66-76.

Reddick, A. 2010. 'Introduction.' W.H. Bond. 'From the Great Desire of Promoting Learning': Thomas Hollis's Gifts to the Harvard College Library. Cambridge, MA: Harvard Library Bulletin, 1-31.

Redford, B. 1990. 'Defying our Master: The Appropriation of Milton in Johnson's Political Tracts.' Studies in Eighteenth-Century Culture, 20: 81-92.

Redford, B. (ed.) 1992-1994. The Letters of Samuel Johnson, 5 vols. Princeton: Princeton University Press. 